\title{
Northland Preparatory Academy: An Expansion Controversy
}

Craig E. Bain, Northern Arizona University, USA

Lawrence C. Mohrweis, Northern Arizona University, USA

\begin{abstract}
This paper deals with a real case in a real situation. Northland Preparatory Academy (NPA) is a college-preparatory charter school located in Flagstaff, Arizona. In 2004, the school board had to decide whether to expand. Their expansion decision was driven by (1) a desire for additional programs in fine arts and music, (2) a desire for a gymnasium for extra curriculum activities, athletics, and related programs, and (3) a belief that the expansion would help with NPA's retention problem at the high school level. The school's principal and several of the school board members were leaning toward constructing a new building. However, there was a minority group on the school board which was adamantly opposed to any expansion and the taking on new debt. Bill Johnson, the school's principal, had been asked by the Chairman of the school board to develop three years' worth of projected financial statements and forecasted cash flow statements assuming that expansion did take place. In addition, Bill was challenged to present information as to whether a new bank loan or taking out a new bond would be best for the school.
\end{abstract}

Keywords: Cash Flows; Forecasts; Charter School; Refinancing; Expansion

\section{INTRODUCTION}

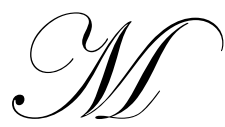

arsha Anderson jumped with joy when she heard the news. ${ }^{1}$ Her daughter had won the lottery. It was not a typical lottery, but an "education lottery." Her daughter, Cathy, had applied to be a 7thgrader at Northland Preparatory Academy (NPA), a 7th through 12th grade college-preparatory charter school located in Flagstaff, Arizona. After the application period had closed, the names of 105 applicants were placed in a lottery. The school had spaces for only 75 new $7^{\text {th }}$ graders. "We numbered the kids" files and pulled names out of a hat essentially," said the jubilant principal Bill Johnson, to a local newspaper reporter. Cathy's name was the third name chosen.

Now, two years later in the Spring of 2004, Bill Johnson was in an anxious mood. He leaned back in his chair, looked out his window, and watched the students exit the building at the end of the school day. Bill recalled a conversation that he had with Marsha Anderson earlier in the day.

"I am going to enroll Cathy into the regular public high school next year," Marsha had told Bill.

"I thought you were happy with NPA," Bill had replied.

"I am. It has been a great $7^{\text {th }}$ and $8^{\text {th }}$ grade experience for Cathy. But, Mr. Johnson, NPA just doesn't offer the fine arts and other activities which are available at the big public high school," Marsha replied.

"Are you really sure you want Cathy to leave? We offer an excellent $9^{\text {th }}$ grade curriculum. You are well aware of our outstanding college placement record," said Bill.

1 The names of individuals have been changed to protect confidentiality. 
"Cathy and I had a long talk. Education is more than just academics," said Marsha with a sigh.

Bill thought back on the conversation. Several of his teachers had told him that students had complained about the lack of fine arts and other extracurricular activities in the upper grades. Bill's own enrollment numbers showed that almost one-third of NPA students moving from middle school to high school had left the school. Clearly, Marsha Anderson was not just a lone wolf who had something to fuss about. Instead, she was like the tip of an iceberg of a much bigger problem. The overall enrollment growth for the last eight years, starting when the school began in 97-98, is shown in Table 1.

Table 1: NPA's Enrollment Growth

\begin{tabular}{|c|c|c|c|c|c|c|c|}
\hline & \multicolumn{2}{|c|}{ Middle School } & \multicolumn{4}{|c|}{ High School } & \multirow[b]{2}{*}{ Total } \\
\hline & $7^{\text {th }}$ & $8^{\text {th }}$ & $9^{\text {th }}$ & $10^{\text {th }}$ & $11^{\text {th }}$ & $12^{\text {th }}$ & \\
\hline 04-05 & 75 & 75 & 46 & 43 & 35 & 22 & 296 \\
\hline 03-04 & 80 & 75 & 50 & 33 & 22 & 11 & 271 \\
\hline 02-03 & 61 & 60 & 35 & 19 & 12 & 6 & 193 \\
\hline 01-02 & 60 & 50 & 26 & 18 & 10 & 4 & 168 \\
\hline 00-01 & 49 & 49 & 27 & 11 & 6 & 8 & 150 \\
\hline 99-00 & 53 & 40 & 17 & 8 & 8 & 9 & 135 \\
\hline $98-99$ & 3 & 15 & 25 & 15 & 10 & 3 & 71 \\
\hline $97-98$ & 0 & 25 & 17 & 5 & 0 & 0 & 47 \\
\hline
\end{tabular}

Source: Northland Preparatory Academy's Internal Records

It was not just fine arts and after-school extracurricular activities that were being impacted by the enrollment decline. Bill realized that the decline of high school students meant that some advanced placement classes pertinent to a college preparatory curriculum could not be offered due to insufficient demand. He contemplated the questions that he needed to bring to his school board. We may need to expand the school. Should we? How do we finance any expansion if we decide it is appropriate?

\section{NPA'S HISTORY}

NPA represented a wave of educational choices which had emerged in the United States in the late 1990s. Education reformers were concerned about catering to thousands of students using only the traditional framework of the big public school environment. As part of the "school choice" movement the charter school materialized as an innovative alternative. A charter school was a school that had been "chartered" for a specific reason. It typically had a much smaller enrollment, as compared to a traditional school, and often had a specialized mission. NPA was chartered to prepare students for college. As a public charter school, NPA received its' funding from the State on a per capita student basis only. This meant that while Bill Johnson and his school board counted on money from the State for the school's day-to-day operations, the State provided no additional funds for buildings and equipment. NPA was fully accredited by the North Central Association, the same organization that accredited the local public schools. The school's mission statement was as follows:

Northland Preparatory Academy will provide a coordinated, individualized program of study that promotes academic excellence and provides educational opportunities for serious secondary students, regardless of gender, ethnic origin, economic status or academic ability.

The school accepted children without regard to academic abilities. However, the school's learning environment provided its mostly college-bound students with rigorous advanced placement courses in English, mathematics, and the sciences. To promote the school's reputation for academic rigor, all entering $7^{\text {th }}$-graders were required to take Latin as a foreign language.

As Principal Bill Johnson thought back about the last school year, his mood turned from gloomy to excited anticipation. What a whirlwind of progress it had been for NPA! Previously, the school was housed in rented facilities and temporary trailers. Now, NPA had successfully purchased, renovated, and moved into a new facility, a 
20,000 square foot building purchased from the W. L. Gore Corporation at a cost of $\$ 1,440,000$, with an additional $\$ 170,000$ spent by NPA to remodel the building. The school board had a budget and expectations with respect to estimated enrollment projections, but the school lacked a strategic plan. In 2004-05 the school's enrollment was 296 students. Table 2 shows the 2004-05 budget and Table 3 illustrates the cost of the existing bank loan.

Table 2: NPA's 2004-2005 Budget

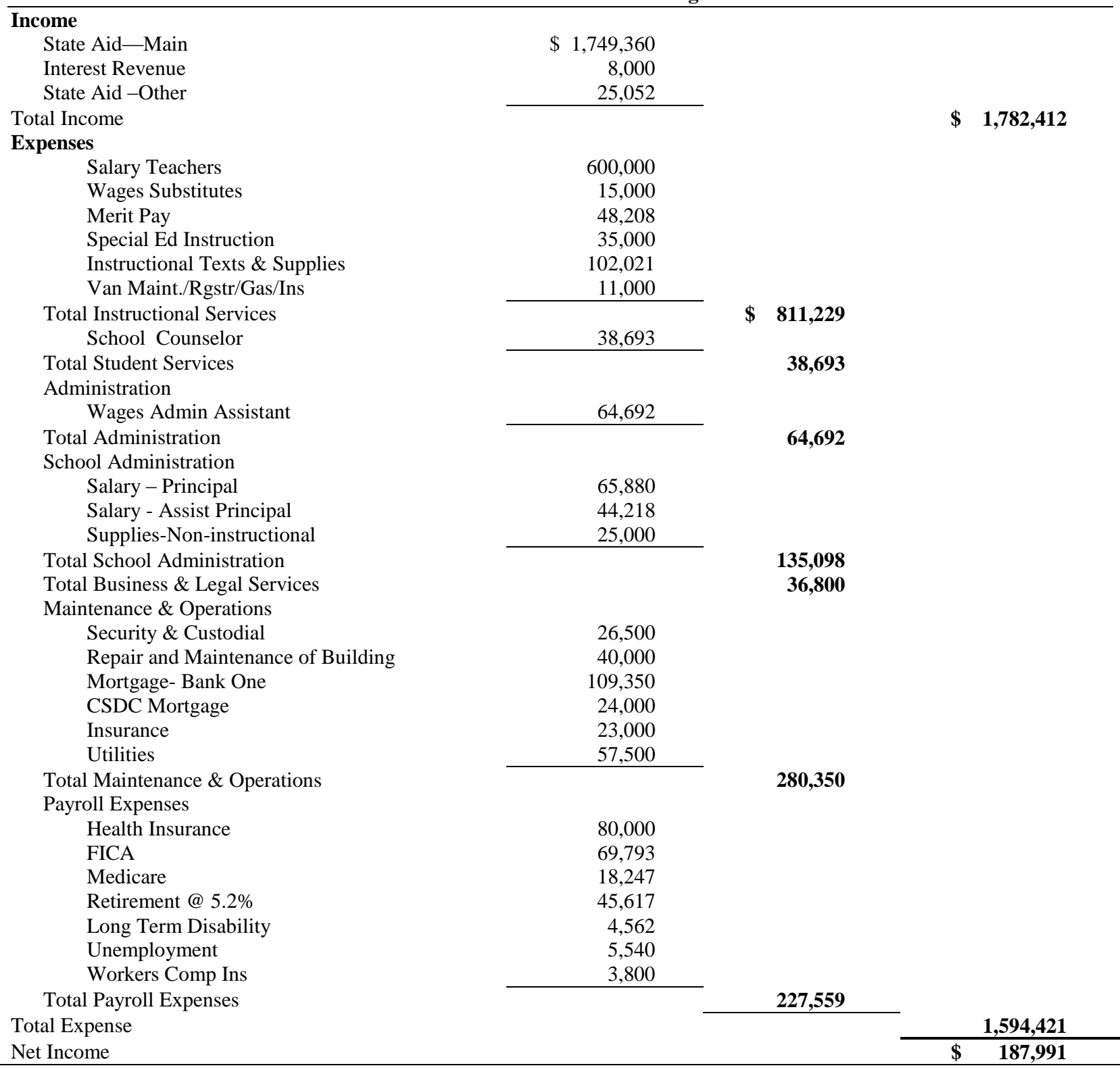

Note: Enrollment at 296 students; Per Capita State Funding at \$5,910 per student. 


\section{Existing Loan}

NPA had an existing loan of $\$ 1,367,000$ from 6/30/03 amortized for 20 years at 5.12 percent. Payments were made monthly. The loan was amortized over 20 years, but the loan must be refinanced in April, 2009.

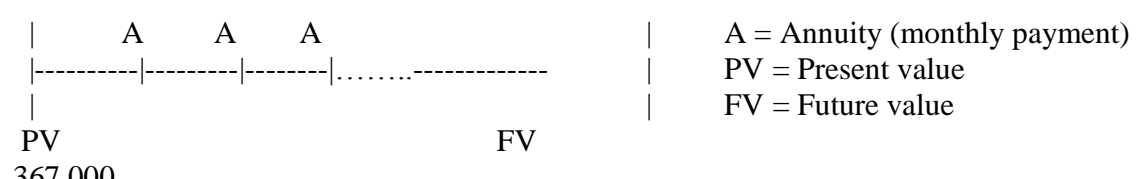

$\$ 1,367,000$

$\mathrm{N}=\mathbf{2 4 0}$ (number of monthly payments)

$\mathrm{I}=\mathbf{5 . 1 2}$ (annual interest rate)

The monthly payment is $\mathbf{\$ 9 , 1 1 2 . 4 6 . ~ T h i s ~ a m o u n t ~ w a s ~ a l r e a d y ~ i n c l u d e d ~ i n ~ N P A ' s ~ 2 0 0 4 - 2 0 0 5 ~}$

No sooner had NPA moved into its new building when the school already seemed overcrowded. At the August 2004 board meeting, after general discussion had ensued, Bill gave his principal/director's report to the board:

"In my director's report to the Board, I want to highlight good news and news that requires the Board's decisions. As some of you are aware, for the first time in the history of NPA, we have reached our capacity for our middle school enrollments. In fact, we were forced to turn away approximately 150 potential students, some of whom have asked to be placed on a waiting list. In addition, we retained a greater percentage of our students moving forward into every high school grade, ” Bill Johnson told his Board of Directors.

“To what do you attribute this enrollment spike?” the Chairman of the School Board asked.

"Two things, first of course is the new building. Many parents have expressed their delight in the new facility. Secondly and related to the building is the location. This location is much better for ease of getting students to school; in addition, we have school parking which allows students with driver licenses to drive to school," Bill replied.

"What this all means is that we, as of this school year, have met our five year enrollment projections in just two years! That's great! In fact, we're already at capacity at our facility. Now, you said you had some decision making news for the board to consider?" the Board Chairman asked.

"Well," continued Bill somewhat hesitantly, "At this point, we cannot take on any more students since we are at our maximum for enrollment in this building. With so many potential students on the $7^{\text {th }}$ grade waiting list, does the Board think we should stay at this current level of enrollment or should we think about expanding?"

It was like a fire alarm going off when Bill made his comments on expansion. A couple of Board members, especially David Victor, became very agitated. NPA had just moved into its new building. The school was a million \& a half dollars in debt. Expansion! Had the Principal gone nuts?

"We barely got the funding to get into this building. We just signed a $\$ 1.4$ million dollar loan, and you're suggesting that we expand? That is a completely irresponsible suggestion," exploded David, with a few other Board member heads nodding in agreement.

While Bill had expected some dissent, he was unprepared and very unsettled by the strong negative reaction. Bill decided that he had to quickly defuse the tension in the room. Turning to the school's volunteer treasurer, who also served on the board, Bill asked the following: 
"Mr. Treasurer, would you give us your financial report for the fiscal year that we just finished? As all of you know, we took July off, so this is the first time we have had an opportunity to review the final financials for last year."

"We ended the year with $\$ 200,000$ in the bank. After we pay for some remodeling and capital improvements, and new teacher raises, we will have about $\$ 125$ thousand cash left in the bank. I think we need to start talking about expansion," the Treasurer responded.

“WHAT!" said David, "We are moving way too fast with all this nonsense talk of expansion. We just took on a \$1.4 million dollar loan."

Board member Elizabeth decided to join in the conversation, "I am very content with the way things are now. We offer a good curriculum, have a stable student enrollment, and have a nice size school. I am opposed to any changes of any kind."

"OK. I appreciate your concern. I think, folks, that we should table this discussion until the next Board meeting," Bill said.

\section{THE LAND DECISION}

What a controversial meeting, thought Bill. But little did he realize that external events would accelerate the controversy. A month later an executive from the W. L. Gore Corporation informed Bill Johnson that the company was willing to sell the empty lot adjacent to NPA for $\$ 73,000$. The offer was good for only 45 days. "Should NPA purchase this empty lot?" thought Bill. "What would the empty lot be used for?" Bill Johnson called the NPA Board quickly together for a special meeting. A short excerpt from that meeting is listed below:

"I have called this special Board meeting as new developments have come up that necessitate a Board decision in the next four weeks. The company that sold us our new building has offered us the $3 / 4$ of an acre that is contiguous to our property. The asking price is $\$ 73,000$," Bill told his Board.

I'm very concerned that we are even having this discussion. I want to go on record as opposing any discussion of expansion at this time," David angrily said, with two other Board members openly agreeing with David.

"If we don't act on this piece of property, it will be developed for homes, and we will be landlocked. We have approximately 45 days to make a decision or the offer will be rescinded," Bill replied.

"What would we use the property for?" the Board Chairman asked.

"It might make sense to think about building a gymnasium and fine arts wing," Bill said.

"This school was chartered to be a college prep school. Athletics and fine arts are unnecessary frivolities. My son is here for the academics and personally I would like to see our monies spent on more AP course offerings," responded Elizabeth.

"Most studies show a high correlation between athletics, fine arts, and academic achievement," replied the teacher representative on the Board, who just happened to be the music teacher.

“Mr. Treasurer, do you have the financial projections I asked you to put together for us?” Bill asked.

"Yes, I do. As you know, we currently have \$125,000 in the bank. This is more than enough to purchase the land, and to have a buffer for the school year. In addition, based on the new higher enrollments, we should have cash left over at the end of each year, " the Treasurer responded. 
"What that says to me is that we can stay at this enrollment level, and use the monies to maintain high academic programs." David replied.

"The company next to us wants to sell us the land for just $\$ 73,000$, yet this land easily has a residential value that is worth almost double that amount! It would be foolish for us not to take advantage of this offer, replied the exasperated Treasurer.

"Folks, we have a lot of information to digest. I suggest we table the discussion until the next Board meeting, at which time, we will have to decide if we want to purchase the land," Bill said.

After the meeting, Bill thought about the land decision. The land is contiguous to the school. It is being offered to the school at a bargain price. The school has sufficient cash to purchase the land. Purchasing the land would be like purchasing an option. NPA could use the land for expansion, and if the land is not used it could always be sold at a profit. Clearly, Bill thought, this was a "no-brainer" decision. Why had it set off such a heated school board discussion? At the school board's regular September meeting the eleven-member school board approved the purchase of the land. However, what surprised Bill was that three school board members voted against it.

Bill decided that he needed to clarify the impetus for expansion. After talking to parents and a few board members, Bill jotted down the following concepts:

1. Expansion is needed because NPA's parents and Board of Directors have a desire for additional programs in fine arts and music.

2. NPA's parents and Board of Directors desire a gymnasium for extra curriculum activities, athletics, and related programs.

3. As a function of points \#1 and \#2 above, the expansion would help with NPA's retention problem at the high school level. A corollary aspect of retaining more high school students would be that NPA could then offer more advanced placement classes.

\section{THE EXPANSION CONTROVERSY}

Shortly after the September meeting, Bill Johnson, at the urging of the Chairman of the school board, obtained cost estimates from a contractor. Building a gymnasium and fine arts wing would cost about three million dollars. Six hundred thousand dollars could be obtained through fund-raising activities; however, at least another $\$ 2,376,000$ would have to be borrowed. Borrowing such an amount would raise the school's total debt load to about $\$ 3.8$ million. The Treasurer informed Bill that the school had two available financing options. NPA could take out a new conventional bank loan or alternatively, obtain bond financing. Table 4 provides information on the loan options.

Before the October 2004 Board meeting, Bill Johnson is asked by the chairman of the school board to prepare projected financial statements and cash flow forecasting statements for the next three years. Some of the key assumptions needed to prepare projected financial statements are listed in Tables 5 and 6.

Table 4: Cost of Proposed Loans

Option 1: New Bank Loan

A new bank loan would be $\$ 2,376,000$; amortized for 20 years at 5.45 percent. It would begin on 6/30/05. Payments would be made monthly. The new bank loan must be refinanced in April, 2009, in conjunction with the existing loan. In addition, the school would have to pay $\$ 24,000$ in origination fees (which must be paid up front from current operational funds).

Option 2: $\underline{\text { Bond Financing }}$

A new bond would be $\$ 4,087,000$ beginning $6 / 30 / 05$, including $\$ 320,000$ in transaction fees. The transaction fees would not be paid up front, but would be included in the $\$ 4,087,000$ bond. The total amount borrowed would be $\$ 4,087,000$. The new bond 
would pay off the existing bank loan on which $\$ 1,367,000$ is owed. There would be a $\$ 60,000$ prepayment penalty on the existing loan. The bond amortization period would be 20 years. The bond interest rate would be at 7.36 percent. This interest rate of $7.36 \%$ was a fixed rate for the entire life of the bond.

The $\$ 4,087,000$ net amount to be borrowed from a bond offering was calculated by the NPA Treasurer as follows:

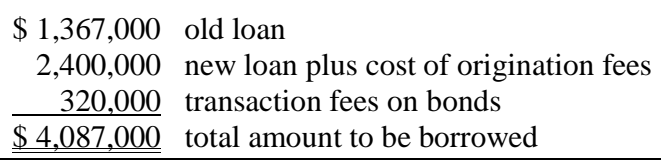

Table 5: Timetable for Expansion \& Enrollment Growth

Timetable for Expansion:

- $\quad$ October 2004 - Determine whether or not to expand

- $\quad$ November 2004 through February 2005 - Prepare architecture designs; develop fund raising campaign

- $\quad$ March 2005 - Break ground on the new building

- July 2006 - Expected date that the building addition would be completed

- $\quad$ August 2006 - Actual date that the building addition was completed

Table 6: Preparing Financial Forecasts

Assumptions for preparing the financial forecasts:

1. Compute revenues by taking the student count multiplied by "Per Capita State Funding" per student (e.g., 296 students times $\$ 5,910=\$ 1,749,360$ for 2004-05). The funding amount per student will increase by a minimum of $2 \%$ per year by State law.

2. Assume no changes in the dollar amount of the following items:

- Interest Revenue; State Aid - Other; Mortgage - Bank One; CSDC Mortgage

3. Assume salaries for administration and special instruction increase by $4 \%$ each year:

- $\quad$ Principal, Assistant Principal, Administrative Assistant

- Special Ed Salary, School Counselor

4. Given the expectation that the building addition will be completed by July 2006, assume the following increases for insurance, utilities, repair \& maintenance, and custodial:

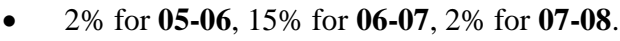

5. To estimate all other expenses, use the percent increase in anticipated enrollments for each year. Specifically, use the following percentages in calculating all other expenses:

- $\quad 7.1 \%$ for $\mathbf{0 5 - 0 6}$ (21 new students divided by last year's base of 296 students)

Small droplets of sweat start to form on Bill Johnson's face as he contemplates the upcoming October 2004 school board meeting and the financial modeling he needs to complete. Although Bill still worries about his people problem - dealing with David Victor and the other conservative board members, his focus is now on preparing budgets and loan options.

\section{ASSIGNMENT QUESTIONS}

1. Prepare a budget which includes any new loan financing using both financing options for the fiscal years of 2005-2006, '06-'07, and '07-'08. The case provides the 2004-'05 financial statements (see Table 2 in the case), along with assumptions needed for preparing the financial forecasts (see Table 6 in the case). In this case, we provide students with a Microsoft Excel spreadsheet.

2. What would the additional monthly payment be on the new bank loan and what would the monthly payment be if the bond financing option is selected?

3. Will the forecasted financial statements provide the necessary cash flow to consider expanding?

4. What are the advantages and disadvantages of the conventional bank loan option versus the bond loan financing option? Which method would you select and why? 


\section{AUTHOR INFORMATION}

Craig E. Bain is a Professor of Accounting at The W. A. Franke College of Business at Northern Arizona University. Professor Bain holds a Ph.D. from Texas A.M., College Station, Texas.

Lawrence C. Mohrweis is a Professor of Accounting at The W. A. Franke College of Business at Northern Arizona University. Professor Mohrweis hold a Ph.D. from the University of Wisconsin - Madison. 